\title{
INTERESTS, IDEAS AND IDEOLOGY: \\ SOUTH AFRICA'S POLICY ON DARFUR
}

\author{
Laurie Nathan*
}

\begin{abstract}
Under former President Mbeki, South Africa provoked international dismay and criticism when it tried to block United Nations censure of Burma, Sudan and Zimbabwe for gross human rights abuses. In the case of Sudan, Pretoria stood accused of turning a blind eye to Khartoum's excessive and indiscriminate violence in Darfur, betraying South Africa's own struggle for democracy and commitment to promoting human rights. This article seeks to shed light on Pretoria's foreign policy by explaining its position on Darfur and exploring the relationship between ideas and interests in shaping the policy. I argue that the position on Darfur was not unfathomable or realist, as some observers claimed, but was based on the core ideas of South Africa's foreign policy: the African Renaissance; quiet diplomacy as the most effective means of dealing with pariah regimes; solidarity with African governments under pressure from the West; and an anti-imperialist paradigm that provided the lens through which the government viewed the global order, defined the country's interests and conceptualised human rights. Whereas most studies of Pretoria's foreign conduct pay little heed to the policies of the ruling party, I show that the conduct flowed logically from the party's anti-imperialist ideology.
\end{abstract}


SOUTH AFRICAN FOREIGN POLICY UNDER FORMER PRESIDENT Thabo Mbeki attracted a great deal of criticism from human rights groups and Western governments. ${ }^{1}$ As a member of the UN Security Council and the UN Human Rights Council, Pretoria attempted to block censure of regimes responsible for gross abuses, most notoriously in the cases of Burma, Sudan and Zimbabwe. ${ }^{2}$ In relation to the humanitarian and human rights crisis that broke out in Darfur in 2003, Pretoria was accused of appeasing Khartoum and turning a blind eye to its iniquitous conduct. ${ }^{3}$ To many observers South Africa's posture was not only objectionable but also baffling and anomalous, wholly inconsistent with the country's historical struggle against oppression and its constitutional embrace of human rights.

In the Human Rights Council, Pretoria worked assiduously to dilute efforts to address the Darfur crisis. For example, in 2006 it opposed a resolution critical of Khartoum's aggression in Darfur, supporting instead a weaker resolution that excluded any reference to follow-up action by the Council and to the Sudanese government's duty to protect civilians. ${ }^{4}$ In 2007, having been elected to the UN Security Council, South Africa backed Sudan in rejecting a resolution that could lead to sanctions against combatants who attacked civilians, obstructed peace initiatives or refused to cooperate with UNAMID, the United Nations-African Union peacekeeping force in Darfur. $^{5}$ Pretoria also opposed a resolution condemning rape as a political and

\footnotetext{
* Laurie Nathan (1.nathan@1se.ac.uk) is Senior Researcher at Pretoria University and Research Fellow at the University of Cape Town.

${ }^{1}$ An earlier draft of this paper was presented at a seminar at the Royal Institute of International Affairs in London on 12 February 2008 and was published as Laurie Nathan, 'Anti-imperialism trumps human rights: South Africa's approach to the Darfur conflict', Working Paper Series, 2, 31 (2008), Crisis States Research Centre, London School of Economics. I would like to thank Chris Alden, Chris Ankersen, Eric Reeves and an anonymous reviewer for their useful comments on the paper.

${ }^{2}$ See Human Rights Watch, 'Letter to the Deputy Minister of Foreign Affairs of South Africa', 13 February 2008, <www.hrw.org/en/news/2008/02/13/letter-deputy-minister-foreign-affairs-southafrica> (24 February 2010); and Anthoni van Nieuwkerk, 'A critique of South Africa's role on the UN Security Council', South African Journal of International Affairs, 14, 1 (2007), pp. 61-77.

${ }^{3}$ Human Rights Watch, 'Letter to the Deputy Minister'; Abdelbagi Jibril, 'South Africa and Darfur fact sheet', Pambazuka News, 321, 27 September 2007, pp. 2-5; Wasil Ali, 'South Africa's stance on Darfur may tarnish its anti-oppression legacy', Sudan Tribune, 22 July 2007; and Hans Pienaar, 'Doomed to be a lost cause despite good intentions', Sunday Independent, 6 January 2008.

${ }^{4}$ United Nations Office at Geneva, 'Human Rights Council notes with concern serious human rights and humanitarian situation in Darfur' (press release, Geneva, 28 November 2006).

5 'Draft resolution calls for 26,000-strong African Union-UN peacekeeping force for Darfur', International Herald Tribune, 11 July 2007.
} 
military instrument, tabled by the United States in the UN General Assembly in 2007, because it believed that the US was targeting the government of Sudan. ${ }^{6}$

In 2007 Mbeki hosted a visit to Cape Town by President Omer El Bashir, the Sudanese head of state. They signed agreements on economic, trade and military cooperation and upgraded the Joint Bilateral Commission set up the previous year from a technical to a ministerial level. ${ }^{7}$ Mbeki went so far as to describe Sudan as a strategic partner of South Africa. The two presidents agreed that the international community should take firm action against the Darfur rebels who were boycotting peace talks in Libya. Mbeki referred pejoratively to the rebels as "choosing to engage in violent actions against the innocent people of Darfur". ${ }^{8}$

Willing to condemn the rebels, at no stage during his presidency did Mbeki voice concern about Khartoum's ethnic cleansing, atrocities and excessive violence against civilians. In 2005 the International Commission of Inquiry on Darfur found that Sudanese government forces and militia had "conducted indiscriminate attacks, including killing of civilians, torture, enforced disappearances, destruction of villages, rape and other forms of sexual violence, pillaging and forced displacement, throughout Darfur"; the Commission concluded that these were "serious violations of international human rights and humanitarian law amounting to crimes under international law". ${ }^{9}$ Nevertheless, Mbeki was prepared to issue a joint statement with Bashir opposing the International Criminal Court (ICC) indictment of the Sudanese president for war crimes, maintaining that this could undermine the resolution of the Darfur conflict and the promotion of lasting peace and reconciliation in Sudan. ${ }^{10}$ Many African countries similarly opposed the ICC indictment and were equally protective of Khartoum in UN forums. Yet South Africa continued to hold out in the

\footnotetext{
${ }^{6}$ Department of Foreign Affairs, 'Notes following media briefing by Deputy Minister Aziz Pahad', 20 November 2007, <www.dfa.gov.za/docs/speeches/2007/paha1121.htm> (30 November 2007).

${ }^{7}$ Department of Foreign Affairs, 'Banquet remarks of the President of South Africa, Thabo Mbeki, in honour of the President of Sudan, Omar Hassan Ahmed El Bashir',

$<$ www.dfa.gov.za/docs/speeches/2007/mbek1107.htm> (19 November 2007).

8 Ibid.

${ }^{9}$ International Commission of Inquiry on Darfur, 'Report of the International Commission of Inquiry on Darfur to the United Nations Secretary-General', Geneva, 2005, $<$ www.un.org/news/dh/sudan/com ing darfur.pdf $>$ (5 February 2010).

${ }^{10}$ Sudanese Media Centre, 'Text of Joint Communiqué issued at conclusion of visit of President Thabo Mbeki to Sudan', 16 September 2008，<www.smc.sd/eng/news-details.html?rsnpid=19217> (3

February 2010).
} 
Human Rights Council even when other African members, including Cameroon, Gabon, Ghana, Mauritius, Nigeria, Senegal, Uganda and Zambia, backed calls for more assertive Council action on Darfur. ${ }^{11}$

What accounts for this apparently incongruous behaviour by a democratic country whose foreign policy encompasses the promotion of human rights? ${ }^{12}$ In this article I show that South Africa's controversial stance was not unfathomable, realist or capricious, as some commentators have claimed. ${ }^{13}$ On the contrary, it was based on the core ideas of the government's foreign policy. In the sections that follow I explain Pretoria's position on Darfur in terms of its Africanist agenda and engagement in continental peacemaking; strategic approach to dealing with pariah regimes; principled solidarity with African governments; commercial relations with Sudan; and anti-imperialist world view, which coloured and sometimes overrode the commitment to human rights. The article then examines the centrality of ideas as determinants of South Africa's foreign policy and locates the Africanist and anti-imperialist paradigms in the experience and ideology of the ruling party, the African National Congress (ANC). I conclude by arguing that while the anti-imperialist posture was meant to be progressive and transformative, the resistance to international pressure on dictatorial regimes was in fact reactionary, shielding and comforting the dictators, forsaking their victims and undermining international protection of human rights.

To convey the relationship between ideas and interests in the political realm, Max Weber famously invoked the image of a railway switchman, claiming that interests rather than ideas "directly govern men's conduct" but "very frequently the "world images' that have been created by ideas have, like switchmen, determined the tracks along which action has been pushed by the dynamic of interests". ${ }^{14}$ Judith Goldstein and Robert Keohane employ the metaphor of ideas as a roadmap: in the political arena

\footnotetext{
${ }^{11}$ Human Rights Watch, 'Letter to the Deputy Minister'; and Human Rights Watch, 'Human Rights Council: act now on Darfur', press release, Geneva, 22 March 2007.

${ }^{12}$ See Department of Foreign Affairs, Strategic Plan, 2003-2005 (Department of Foreign Affairs, Pretoria, 2004).

${ }^{13}$ For example, Pienaar, 'Doomed to be a lost cause'; and Peter Vale, 'Thabo Mbeki: my part in his downfall', paper presented at the annual meeting of Theory vs. Policy? Connecting Scholars and Practitioners, New Orleans, 17 February 2010, <www.allacademic.com/meta/p417075 index.html $>$ (25 February 2010).

${ }^{14}$ Quoted in Judith Goldstein and Robert Keohane, Ideas and Foreign Policy (Cornell University Press, Ithaca, NY, 1993), pp. 11-12.
} 
where actors face continual uncertainties about their interests and how to maximise them, ideas serve to guide behaviour either by stipulating causal patterns or by providing compelling ethical motivations for action. ${ }^{15}$ In the case of South Africa's foreign policy, the role of ideas is best captured by the metaphor of a lens. The antiimperialist and Africanist paradigms provided a normative and analytical lens for understanding the international order, conceptualizing human rights, defining the country's interests and formulating the vision, goals, priorities and strategies of foreign policy.

\section{Peacemaking in Africa}

The first set of factors that account for South Africa's supportive attitude towards Khartoum flowed from Pretoria's foreign policy priority, the political and economic revitalisation of Africa, which was encapsulated by Mbeki's vision of an African Renaissance and the strategic programme known as the New Economic Partnership for Africa's Development (Nepad). ${ }^{16}$ The logic of Nepad is that Africa's recovery depends on sustained development, investment and economic growth, which in turn require good governance, peace and stability. To this end, Mbeki played a prominent peacemaking role on the continent, undertaking mediation to end civil conflict in Burundi, the Comoros, the Democratic Republic of Congo, the Ivory Coast, Lesotho and Zimbabwe. South Africa also participated in UN peacekeeping missions in Africa and contributed personnel to the African Mission in Sudan (AMIS), the AU's peacekeeping force in Darfur.

Pretoria attached great importance to Sudan's Comprehensive Peace Agreement (CPA), which in 2005 ended the decades-long war between the ruling National Congress Party (NCP) and the Sudan People's Liberation Movement (SPLM) led by John Garang in southern Sudan. After concluding the agreement the two parties formed a Government of National Unity, creating the potential for desperately needed reconstruction and development in the war-shattered south. At the end of 2004 Mbeki witnessed the signing of the ceasefire accord in the Kenyan town of Naivasha, in 2005

\footnotetext{
${ }^{15}$ Ibid, pp. 13-17.

${ }^{16}$ Thabo Mbeki, 'Address to the joint sitting of the National Assembly and the National Council on the New Partnership for Africa's Development', Cape Town, 31 October 2001, $<$ www.dfa.gov.za/docs/speeches/2001/mbek1031.htm $>$ (12 February 2010).
} 
Deputy President Jacob Zuma attended the signing of the CPA in Nairobi and Mbeki thereafter travelled to Khartoum for the inauguration of the Government of National Unity. As the chair of the AU's ministerial committee on post-conflict reconstruction in Sudan, South Africa has remained an avid champion of the CPA.

The CPA was tenuous from the outset, however, with the NCP frequently accused of failing to honour its obligations. ${ }^{17}$ Amid widely held fears of a resumption of war and the possible break-up of Sudan, Pretoria prioritized the CPA and the south above Darfur. In 2006, for example, South Africa’s Minister of Intelligence, Ronnie Kasrils, devoted a speech on international support for peacebuilding in Sudan almost exclusively to the CPA. At a time of fierce fighting in Darfur after the collapse of the Darfur Peace Agreement, Kasrils referred to Darfur only in relation to the CPA, declaring that "we need to ensure that the implementation of the CPA... is not overshadowed and undermined by events in Darfur". ${ }^{18}$ These comments reflected Pretoria' concern that international donors, agitated by Khartoum's brutal response to the Darfur rebellion, were not meeting their pledges to fund the rebuilding of southern Sudan. ${ }^{19}$

The priority that South Africa placed on the CPA and the south stemmed partly from the ANC's political affinity with the SPLM and its support for Garang's vision of a secular and democratic Sudan. When Garang died in a plane crash in 2005 Mbeki attended his funeral and, remarkably, two days after the crash South Africa's Foreign Minister and the ANC Secretary-General went to southern Sudan to help the SPLM manage the crisis. $^{20}$ The South African government subsequently provided training assistance to the SPLM to strengthen its capacity for governance. ${ }^{21}$ By contrast, the ANC had no affinity with the politically unsophisticated Darfur rebels. Pretoria prioritised the CPA for the additional reason that it regarded the agreement as an

\footnotetext{
${ }^{17}$ International Crisis Group, 2006, 'Sudan's Comprehensive Peace Agreement: the long road ahead', Africa Report, 106, 2006.

${ }^{18}$ Ronnie Kasrils, 'Address by Mr Ronnie Kasrils, MP, Minister for Intelligence Services, Chatham House, at [the seminar on] The International Community and Building Peace in Sudan', 2006, $<$ www.info.gov.za/speeches/2006/06122113451001.htm> (3 February 2010).

${ }^{19}$ See Mbeki's remarks in 'South Africa to send more peacekeepers to Sudan', Sudan Tribune, 29 November 2007.

${ }^{20}$ Thabo Mbeki, 'Long live the spirit of John Garang!', Letter from the President, ANC Today, 5, 31, 511 August 2005, pg. 1, < www.anc.org.za/ancdocs/anctoday/2005/text/at31.txt $>$ (15 November 2007).

${ }^{21}$ Department of Foreign Affairs, 'Banquet remarks'.
} 
appropriate framework for resolving the Darfur crisis and establishing a "viable, stable and democratic federal state". ${ }^{22}$

In relation to Darfur, Mbeki focused on the necessity of mounting a UN peacekeeping operation. AMIS was so under-resourced and ineffectual in the midst of intense violence that its replacement by a larger and better equipped international force was widely held to be essential and urgent. Khartoum was strongly opposed to this move, however, and Mbeki laboured to overcome its obduracy. In 2006 he went to Sudan to press Bashir to approve a UN takeover of AMIS; ${ }^{23}$ when he visited Sudan the following year one of his aims was to encourage implementation of the AU-UN agreement on UNAMID; ${ }^{24}$ and when he hosted Bashir in Cape Town in 2007 he insisted that UNAMID should be deployed without further delay. ${ }^{25}$ Given Pretoria's strategic perspective on dealing with pariah regimes, discussed in the following section, Mbeki believed that his mission to sway Bashir required 'quiet diplomacy' and that public criticism would diminish his influence.

\section{Pariahs, Solidarity and Commerce}

A second explanation for Pretoria's efforts to block UN censure of Khartoum lies in its conviction that the international community is most likely to induce positive change in pariah regimes - like Zimbabwe, Burma, Iran and Sudan - through diplomatic engagement. Condemnation, coercion and isolation, it argued, would only heighten the regime's intransigence. Foreign Minister Nkosazana Dlamini-Zuma summed up this perspective as follows: "Our own national experience has taught us the value of seeking negotiated solutions to problems, no matter how intractable they may at first seem, and of engaging all the relevant role players in a dialogue". ${ }^{26}$

\footnotetext{
${ }^{22}$ Thabo Mbeki, 'An African prayer for peace', Letter from the President, ANC Today, 6, 18, 12-18 May 2006, pg. 2, <www.anc.org.za/ancdocs/anctoday/2006/at18.htm> (15 November 2007).

${ }^{23}$ Andrew Quinn, 'South Africa's Mbeki to push Sudan on UN peace force', Reuters news release, 13 June 2006.

${ }^{24}$ Department of Foreign Affairs, 'President Thabo Mbeki to hold discussions with Sudanese President and First Vice President in Khartoum and Juba', media release, 9 April 2007, $<$ www.dfa.gov.za/docs/2007/suda0409.htm $>$ (28 November 2007).

${ }^{25}$ Department of Foreign Affairs, 'Banquet remarks'.

${ }^{26}$ Nkosazana Dlamini-Zuma, 2007, 'Address by the Minister of Foreign Affairs, Dr Nkosazana Dlamini-Zuma, to the National Assembly on the occasion of the budget vote of the Department of Foreign Affairs, Cape Town', 29 May 2007, pg. 6.
} 
Dlamini-Zuma added that this thinking had greatly influenced South Africa's votes in the UN Security Council in $2007 .^{27}$

In relation to the Security Council's concerns about Iran's nuclear programme, South Africa maintained that sanctions "should be utilised with great caution, and only to support the resumption of political dialogue and negotiations to achieve a peaceful solution"; negotiations were essential because "no one will win through a process of confrontation that can lead to disastrous consequences in a highly volatile region". ${ }^{28}$ In the case of Burma, South Africa voted against a Security Council resolution urging the junta to ease repression and release political prisoners, asserting that the resolution would compromise the 'good offices' of the UN Secretary-General, whose recent diplomatic forays had opened a "window of hope and communication". 29

The most prominent example of Pretoria's preference for soft diplomacy was its approach to the political crisis in Zimbabwe. In response to critics who cried out for an emphatic denunciation of Harare's violations of human rights and the rule of law, government officials were adamant that 'shouting from the rooftops', as they put it, would accomplish nothing. Mbeki said scornfully that his detractors were mistaken if they believed that Zimbabwe's leaders would "meekly obey what the baas across the Limpopo would have told them". ${ }^{30}$ In adopting this approach, Pretoria was influenced by its experience in 1995 when President Mandela called for sanctions to be imposed on the Abacha dictatorship in Nigeria and was soundly rebuffed by other African leaders and the Organisation of African Unity. In 2001 the head of the ANC's department of international relations justified the policy of 'quiet diplomacy' towards Zimbabwe by proclaiming that Pretoria would not repeat Mandela's "terrible mistake"

\footnotetext{
27 Ibid.

${ }^{28}$ Dumisani Kumalo, 'Statement by Ambassador DS Kumalo, Permanent Representative, to the United Nations Security Council on non-proliferation', 24 March 2007, $<$ www.southafrica-newyork.net $>$ (8 January 2008).

${ }^{29}$ Dumisani Kumalo, 'Statement by Ambassador Dumisani Kumalo at the Security Council meeting on the situation in Myanmar', 12 January 2007, <www.southafrica-newyork.net> (8 January 2008).

${ }^{30}$ Thabo Mbeki, 'The people of Zimbabwe must decide their own future', Letter from the President, ANC Today, 3, 18, 9-15 May 2003， <www.anc.org.za/ancdocs/anctoday/2003/at18.htm> (2 August 2005).
} 
when he acted as a "bully" against the Nigerian dictatorship and "everyone stood aside and we were isolated". 31

These comments capture the third major reason for Pretoria's silence on Sudan's human rights abuses, namely the political culture of unity and solidarity that inhibits African governments from criticising each other publicly. Forged in the heat of the struggles against colonial rule, this posture remains a strategic imperative for weak regimes that are buffeted by domestic and external challenges. Notwithstanding their differences and disputes, the regimes close ranks when they are under pressure from the West. Knox Chitiyo describes the tendency as an ideology of "patriotic blackness". ${ }^{32}$ It can also be understood as an anti-imperialist construct since it is expressed through a discourse of resistance to 'the dictates of the neo-colonial powers' and it is not confined to African governments but encompasses developing countries elsewhere in the world.

It is possible that a fourth explanation for Pretoria's protective attitude towards Khartoum is to be found in the commercial sphere. When Mbeki visited Sudan in 2004 he was accompanied by a high-level delegation of business people, resulting in an agreement to co-operate on oil exploration. ${ }^{33}$ PetroSA, South Africa's national oil company, signed a deal for exclusive oil concession rights in a designated area and the Global Railway Engineering Consortium of South Africa concluded a \$21 million contract with the Sudanese Railway Corporation. ${ }^{34}$ Between 2000 and 2008 the annual value of South African exports to Sudan rose from \$6.6 million to \$57 million. ${ }^{35}$

\footnotetext{
${ }^{31}$ Jaspreet Kindra, 'We won't make the same mistake with Zimbabwe', Mail and Guardian, 2 March 2001, http://www.zimbabwesituation.com/mar04.html\#link6

${ }^{32}$ Knox Chitiyo, 'Patriotic blackness: Africa and the crisis in Zimbabwe', RUSI Newsbrief, 27, 8 (2007), pp. 91-93.

${ }^{33}$ Department of Foreign Affairs, 'Joint communiqué of the official visit to the Republic of Sudan by His Excellency President Thabo Mbeki, 30 December 2004 - 2 January 2005’, 2005, $<$ www.dfa.gov.za/docs/2005/suda0103.htm> (28 November 2007).

${ }^{34}$ Peter Fabricius, 'PetroSA to send technicians to explore oil possibilities in the Sudan', Sudan Tribune, 10 January 2005, <www.sudantribune.com/spip.php?article7465> (2 February 2010).

${ }^{35}$ These figures were retrieved from the South African Department of Trade and Industry website at www.thedti.gov.za/econdb/raportt/R100107.html (28 January 2010). The US dollar figures are based on an exchange rate of $\$ 1.00=$ ZAR7.5.
} 
While these growing commercial ties might have contributed to Pretoria turning a blind eye to Khartoum's brutality in Darfur, their weight as an explanatory factor should not be overstated. In 2008 South Africa's exports to Sudan amounted to less than $1 \%$ of its total annual exports and Sudan was placed a lowly 81 in the country ranking of South African exports by value. ${ }^{36}$ In 2009 PetroSA disposed of its oil exploration rights in Sudan. ${ }^{37}$ In general, the promotion of bilateral trade and investment has not been a significant factor in shaping Pretoria's stance on African and global crises.

\section{The Anti-Imperialist Agenda}

In 2007 the African edifice of solidarity cracked under the weight of Darfur's unremitting humanitarian disaster and Khartoum's persistent bellicosity and intransigence, with Cameroon, Gabon, Ghana, Mauritius, Nigeria, Senegal, Uganda and Zambia supporting calls for more assertive action on Darfur by the UN Human Rights Council. ${ }^{38}$ South Africa, on the other hand, remained protective of Khartoum. Whatever the strength of the explanations offered above, Pretoria's hard-line stand can only be properly understood in the light of the anti-imperialist core of its foreign policy. In essence, under the Mbeki administration foreign policy was based on three paradigms: democratic; Africanist; and anti-imperialist. Whereas the Africanist and anti-imperialist paradigms were seldom if ever in conflict with each other, both were occasionally in conflict with the democratic paradigm. In these instances, as discussed below, the democratic position gave way.

The anti-imperialist core revolved around the following themes: the iniquitous political and economic power imbalance between the North and the South, to the great detriment of the poor; the dire need to reform the UN, the Bretton Woods institutions and other international organizations in order to address the power imbalance and resultant inequities; the domineering and hypocritical approach of Western states that

\footnotetext{
${ }^{36}$ These figures were retrieved from the South African Department of Trade and Industry website at www.thedti.gov.za/econdb/raportt/rapcoun.html (28 January 2010).

${ }^{37}$ Chanel Pringle, 'PetroSA posts R1,96bn profit, revenue hits record', Engineering News, 10 November 2009, <www.engineeringnews.co.za/article/petrosa-posts-r196bn-profit-revenue-hitsrecord-2009-11-10> (5 February 2010).

${ }^{38}$ Human Rights Watch, 'Letter to the Deputy Minister'; and Human Rights Watch, 'Human Rights Council: act now on Darfur'.
} 
use these organizations to chide and bully developing countries while ignoring such reprehensible behaviour as Israel's occupation of Palestine; South-South co-operation and solidarity as a form of collective strength; and multilateralism and respect for international law as the only legitimate basis for inter-state relations and the resolution of international crises. ${ }^{39}$ Mbeki situated the African Renaissance squarely within this anti-imperialist paradigm, calling on Africans to deliver themselves from the legacy of colonialism and neo-colonialism and meet the challenges of economic globalization that further weakened the sovereignty and economies of African countries. $^{40}$

An activist agenda flowed from this perspective: Pretoria campaigned for debt relief for poor countries, the transformation of the global trading system and reform of the UN Security Council; worked to build coalitions of developing countries around these issues; championed the cause of Africa in numerous international forums; and chaired the AU, the Non-Aligned Movement, the Southern African Development Community, the Commonwealth, the UN Conference on Trade and Development and the UN Security Council. ${ }^{41}$ In the UN General Assembly, Mbeki repeatedly raised the problem of global power inequities with a marked sense of anger and frustration. In 2007, for example, he made the following remarks:

Because the nations of the world are defined by the dominant and the dominated, the dominant have also become the decision makers in the important global forums, including at this seat of global governance. Accordingly, the skewed distribution of power in the world - political, economic, military, technological and social - replicates itself in multilateral institutions, much to the disadvantage of the majority of the poor people of the world. Indeed, even as we agree on the important programmes that

\footnotetext{
${ }^{39}$ These themes are drawn from President Mbeki's foreign policy speeches, available at www.thepresidency.gov.za, and from his columns in ANC Today,

<www.anc.org.za/ancdocs/anctoday $>$ (4 February 2010). See also Department of Foreign Affairs, Strategic Plan.

${ }^{40}$ Rok Ajulu, 'Thabo Mbeki's African Renaissance in a globalising world economy: the struggle for the soul of the continent', Review of African Political Economy, 28, 87 (2001), pp. 27-42.

${ }^{41}$ See Chris Alden and Garth le Pere, 'South Africa's post-apartheid foreign policy: from reconciliation to ambiguity?' Review of African Political Economy, 31, 100 (2004), pp. 283-297; and Adam Habib, 'South Africa's foreign policy: hegemonic aspirations, neoliberal orientations and global transformation', South African Journal of International Affairs, 16, 2 (2009), pp. 143-159.
} 
should bring a better life to billions of the poor, the rich and the powerful have consistently sought to ensure that whatever happens, the existing power relations are not altered and therefore the status quo remains. ... Indeed, until the ideals of freedom, justice and equality characterise this premier world body, the dominant will forever dictate to the dominated and the interests of the dominated, which are those of the majority of humanity, would be deferred in perpetuity. ${ }^{42}$

Viewed through the anti-imperialist prism, Pretoria regarded the international human rights arena as a site of struggle between the North and the South. According to Dumisani Kumalo, South Africa's permanent representative to the UN between 1999 and 2009, the developed and developing countries 'are locked in a 'cold war' on the correct approach to human rights" because the developed countries sit in judgement of the governance and human rights performance of selected developing countries. ${ }^{43}$ This gives rise to "double standards, hypocrisy, and the abuse of the UN's human rights machinery [by the developed countries] to serve national political agendas"; it also "leads to a situation where developing countries are forced to rally to the support of the targeted country, irrespective of its actual human rights performance" . ${ }^{4}$

Pretoria raised similar concerns about the UN Security Council. The critique ran thus: whereas the General Assembly is a representative and democratic forum in which the balance of forces does not favour any state, the Council's arrangements privilege the five permanent members (P-5), which enjoy the right of veto; the P-5 therefore want the issues they deem important to be dealt with in the Security Council even if this encroaches on the mandate of organs, such as the Human Rights Council, that fall under the General Assembly. ${ }^{45}$ Moreover, the P-5 control the process of defining international security and determining the existence of threats. Developing countries have watched powerlessly as the Security Council has become increasingly intrusive in this regard, assuming quasi-judicial authority and directing states to amend their

\footnotetext{
42 Thabo Mbeki, 'UN Speech at the $62^{\text {nd }}$ session of the United Nations General Assembly', New York, 25 September 2007, <www.anc.org.za/ancdocs/history/mbeki/2007/tm0925.html > (25 January 2008).

${ }^{43}$ Quoted in van Nieuwkerk, 'A critique of South Africa's role', pg. 72.

${ }^{44}$ Ibid. Emphasis added.

${ }^{45}$ Dlamini-Zuma, 'Address by the Minister of Foreign Affairs'.
} 
national laws. ${ }^{46}$ This critique led Pretoria to oppose the Security Council resolutions on the human rights situations in Burma and Zimbabwe in 2007, arguing that these situations lay outside the Council's mandate on international threats to peace and security. ${ }^{47}$

The dominance of the anti-imperialist paradigm and subordination of human rights were illustrated vividly by Pretoria's rejection of the resolution on rape proposed by the US in the UN General Assembly in November 2007. The US sought to condemn the use of rape as a political and military instrument by governments and armed groups. South Africa objected formally on the grounds that a narrow focus on rape as a weapon of war might imply that other types of rape were less horrible. ${ }^{48}$ This argument seemed disingenuous since Pretoria had previously endorsed UN Security Council Resolution 1325 of 2000, which calls for the elimination of grave sexual violence against women and girls during armed conflict. Indeed, when South Africa held the presidency of the Security Council in March 2007, it issued a presidential statement reaffirming support for Resolution $1325 .{ }^{49}$ The underlying motivation for Pretoria's objection was its belief, articulated by Deputy Foreign Minister Aziz Pahad, that the US was "politicising" the crime of rape in a selective manner with Khartoum as the target. ${ }^{50}$ Kumalo elaborated as follows: "Rape was used in the Balkans; soldiers were encouraged to do it in places like Srebrenica, but the US did not bring any resolution then to condemn those people. Now that the US wants everyone to know it is having a fight with Sudan, they bring it, and they are trying to use it as a tool for their own purposes". 51

The anti-imperialist paradigm provides a strong explanation for Pretoria's resistance to Western pressure on Sudan, which it saw as redolent of colonialism. The solidarity engendered by the paradigm, notwithstanding the NCP's fundamentalist and

\footnotetext{
${ }^{46}$ Dumisani Kumalo, quoted in van Nieuwkerk, 'A critique of South Africa's role', pg. 64.

${ }^{47}$ Van Nieuwkerk, 'A critique of South Africa's role'.

${ }^{48}$ Rowan Philp, 'SA, US clash over attempt to condemn rape in war', The Times [South Africa], 11 November 2007; and 'SA responds to US in UN rape resolution row', Mail\&Guardianonline, 10 November 2007, <www.mg.co.za> (7 December 2007).

${ }^{49}$ UN Department of Public Information, 'Security Council stresses importance of women's equal participation, full involvement in efforts to maintain peace, security', press release, 7 March 2007, $<$ www.un.org/News/Press/docs/2007/sc8967.doc.htm> (28 January 2008).

${ }^{50}$ Department of Foreign Affairs, 'Notes following media briefing'.

${ }^{51}$ Philp, 'SA, US clash'.
} 
oppressive character, is captured forcefully by Mbeki's speech in the Sudanese National Assembly in 2004. Mbeki focused on the need for solidarity between the two countries because of their similar colonial histories and struggles for liberation. $\mathrm{He}$ denounced the "eminent representatives of British colonialism" - General Gordon, Field Marshall Wolseley, Lord Kitchener and Winston Churchill - who had played destructive roles in Sudan and had also been present in South Africa, "doing terrible things wherever they went, justifying what they did by defining the native peoples of Africa as savages that had to be civilised even against their will". ${ }^{52}$ This shared colonial past, which "left both of us with a common and terrible legacy of countries deeply divided on the basis of race, colour, culture and religion", should provide a basis for the two countries to work together to build the post-colonial future. ${ }^{53}$

When Mbeki delivered this address it was a moment of dawning peace in southern Sudan after the signing of the Naivasha ceasefire accord but it was also a time of extensive violence and suffering in Darfur. Yet he devoted only a few lines to the crisis there, merely expressing confidence that the situation would be resolved by the Sudanese leadership in co-operation with the AU. Shortly before speaking in the National Assembly, Mbeki had visited Darfur and spoken to representatives of AMIS, the rebel movements, internally displaced people and international humanitarian organisations. ${ }^{54}$ He must have gained a good picture of Khartoum's depravations in the region but this picture was out of sync with the anti-imperialist agenda and fell by the wayside. ${ }^{55}$

\footnotetext{
52 Thabo Mbeki, 2005, 'Address by the President of South Africa, Thabo Mbeki, to the National Assembly, Omdurman, Sudan', 1 January 2005, $<$ www.info.gov.za/speeches/2005/05010315151001.htm> (5 May 2008). 


\section{Ideas and interests in foreign policy}

Research and theories that seek to explain the policies adopted by governments are dominated by rationalist and other materialist accounts that concentrate on the pursuit of interests and pay little attention to the role and impact of ideas. ${ }^{56}$ Yet it seems clear from the preceding sections that ideas have been pivotal in shaping the vision, goals and strategies of Pretoria's foreign policy. The vision and goals include grand ideals (e.g. the African Renaissance and equitable global relations); they rest on ethical and normative principles (e.g. equity, human dignity and respect for international law); and they are pursued through strategies based on ideas about the relationship between means and ends (e.g. democratic governance and neo-liberal economic policies as the route to the African Renaissance, and negotiations as the most effective way of addressing conflicts and crises).

The literature that does explore the role of ideas in policy-making focuses on the following questions: What are the different types of idea that influence policy? What are the causal mechanisms by which ideas effect policy? What are the sources of these ideas? And how do ideas relate to interests in policy formulation? ${ }^{57}$ In a review of this literature, John Campbell constructs a typology of the ideas that have been the subject of research: cognitive paradigms or world views, which are taken-for-granted descriptions and theories that specify cause and effect relationships, reside in the background of policy debates and limit the range of options that policy-makers might consider useful; normative frameworks, comprising taken-for-granted assumptions about values, attitudes, identities and principled beliefs, which also lie in the background of policy debates but constrain action on the grounds of legitimacy and moral or social appropriateness rather than effectiveness; world culture, consisting of transnational cognitive or normative perspectives that account for policy similarities among countries (e.g. environmental policies); frames, which are ideas that policymakers use to legitimise and win support for their policies and are thus located in the foreground of policy debates; and programmatic ideas, which are precise causal

\footnotetext{
${ }^{56}$ John Campbell, 'Ideas, politics, and public policy', Annual Review of Sociology, 28 (2002), pp. 2138 , p. 21.

${ }^{57}$ Campbell, 'Ideas, politics, and public policy'; and Goldstein and Keohane, Ideas and Foreign Policy.
} 
ideas, also at the foreground of debates, that facilitate policy-making by specifying how to solve particular problems. ${ }^{58}$

As discussed in the previous sections, cognitive paradigms and normative frameworks were central components of South African foreign policy under Mbeki. In contrast to Campbell's portrayal, however, they were not limited to 'taken-for-granted' ideas, they did not lie in the background of policy debates and they did more than constrain policy options. Instead, the Africanist and anti-imperialist concepts and values were at the forefront of an exceedingly ambitious foreign policy whose goals included "the eradication of poverty and underdevelopment" and "the transformation of our continent and the global environment". 59 The concepts and values produced a foreign policy characterized by idealism, activism and a kind of secular evangelism. A set of ideas drove the policy and the policy was intended to promote those ideas.

To claim that ideas are determinants of foreign policy is not to say that they are more important than interests or that ideas and interests are dichotomous. Rather, the linkages between ideas and interests should be viewed as a rich terrain for empirical investigation and theoretical reflection when seeking to explain the content of government policies and the varied responses of different countries to common problems. As illustrated below with reference to Campbell's typology, the foreign policy of even a single country can exhibit a range of different relationships between ideas and interests.

In the case of world culture, transnational ethical concerns can become so compelling that they override established interests and practices. For example, in the early 1990s a dynamic international campaign evoked outrage at the indiscriminate damage caused by anti-personnel landmines, leading Pretoria to ban their use, production and trade despite the claim by the Department of Defence that 'smart mines' were needed to protect the country. ${ }^{60}$ Conversely, commercial and strategic interests can override codified norms and principles. Here, too, armaments provide a good example. In the

\footnotetext{
${ }^{58}$ Campbell, 'Ideas, politics, and public policy'.

${ }^{59}$ Nkosazana Dlamini-Zuma, 'Message from the Minister of Foreign Affairs, Dr NC Dlamini Zuma', 2004, in Department of Foreign Affairs, Strategic Plan, pg. 7.

60 'South Africa', website of Landmine Monitor, $<$ http://lm.icbl.org/index.php/publications/display?url=lm/1999/south africa.html\#fnB228 $>$ (15 February 2010).
} 
1990s human rights activists in South Africa campaigned for an ethically responsible policy on arms exports, resulting in legislation prohibiting exports to governments that systematically violate or suppress human rights and fundamental freedoms. ${ }^{61}$ Disregarding this injunction, the executive has granted contracting authorisations or export permits for arms transfers to China, Egypt, Iran, Libya, Saudi Arabia, Syria and Zimbabwe. ${ }^{62}$ Notwithstanding Pretoria's anti-imperialist posture and fierce criticism of the illegal invasion of Iraq in 2003, it also regularly sells weaponry to the US and the United Kingdom.

In the case of programmatic ideas, a shift in analytical perspective can lead to an entirely different approach to a particular problem even though there has been no change in interests. As noted earlier, the Mbeki government subordinated the plight of Darfur to the survival of the CPA and regarded the CPA as the platform for resolving the Darfur conflict. The government of Jacob Zuma, which took office in 2009, turned that position on its head, arguing that the Darfur conflict "does not fall within the parameters of the CPA"; that "failure to address the root causes of conflict in Darfur could ultimately lead to the unravelling of the CPA"; and that the human rights violations and humanitarian crisis in Darfur "are of such a magnitude that we cannot afford to dissociate ourselves from this ongoing conflict". 63

In the case of normative frameworks and cognitive paradigms, ideas can provide the basis for defining interests. This is a key plank of the constructivist school of International Relations, which rejects an exclusively materialist conception of states and the international system and aims instead to explain state interests and conduct in terms of intersubjectively constituted identities and meanings. ${ }^{64}$ It might be selfevident that foreign policy should serve to defend and advance national interests but the nature of these interests is not self-evident and they do not derive simply from a

\footnotetext{
${ }^{61}$ Republic of South Africa, National Conventional Arms Control Act (2002).

${ }^{62}$ Guy Lamb (ed.), The Conventional Arms Trade and its Control in Africa (Institute for Security Studies, Pretoria, 2009), p. 9; and Department of Justice and Constitutional Development, 'NCACC [National Conventional Arms Control Committee] statement on South African arms sales regulation', media statement, 6 August 2009.

${ }^{63}$ Ebrahim Ebrahim, 'Reply to the budget vote by the Deputy Minister of International Relations and Cooperation, Mr Ebrahim Ismail Ebrahim, to the National Assembly', in Department of International Relations and Cooperation, Budget 2009, Pretoria, 2009, pp. 33-34. (In 2009 the Department of Foreign Affairs changed its name to Department of International Relations and Co-operation).

${ }^{64}$ For example, Alexander Wendt, 'Anarchy is what states make of it: the social construction of power politics’, International Organisation, 46, 2 (1992), pp. 391-425.
} 
state's objective place in the international system. Rather, a country's 'national interests' are socially constructed and historically contingent, reflecting an interpretation of the world and the country's place therein. ${ }^{65}$ Whereas a narrow construction might focus on safeguarding sovereignty, territorial integrity and the political system, the Africanist and anti-imperialist pillars of South Africa's foreign policy gave rise to an expansive conception of national interests and their attainment. According to Deputy Minister Pahad:

It is important to emphasise that South Africa's foreign policy is premised upon its national interests, domestic policies and values. Domestically, South Africa is committed to bringing about a better life for all in an environment of peace, stability and security. This objective [can] only be achieved in an international environment characterised by global peace and security and an equitable and just system. ${ }^{66}$

In addition to defining interests, causal and normative ideas can be influential where a government has to choose between conflicting interests and alternative courses of action. In relation to both Sudan and Zimbabwe, Pretoria appeared to believe that there were two mutually exclusive options, each of which had significant costs: it could either maintain solidarity with Harare and Khartoum, thereby incurring the displeasure of its Western partners, damaging its international reputation on human rights and prejudicing donor support for Nepad, or it could join the Western critics and thereby risk alienating its African partners and weakening its standing on the continent. The adoption of the former option flowed logically from the Africanist and anti-imperialist paradigms and from the strategic idea that quiet diplomacy is more effective than censure and isolation.

The two paradigms do not constitute a set of binding rules and do not account for every aspect of South Africa's foreign conduct which, like that of other states, has

\footnotetext{
${ }^{65}$ Jutta Weldes, 'Constructing national interests', European Journal of International Relations, 2, 3 (1996), pp. 275-318. See also Anthoni van Nieuwkerk, 'South Africa's national interest', African Security Review, 13, 2 (2004), pp. 89-101.

${ }^{66}$ Aziz Pahad, 'Message from the Deputy Minister of Foreign Affairs, Aziz Pahad', 2004, in Department of Foreign Affairs, Strategic Plan, pg. 9.
} 
inconsistencies and contradictions. ${ }^{67}$ For example, Patrick Bond argues that Mbeki's anti-imperialist discourse was completely at odds with his embrace of neo-liberal economic policies. ${ }^{68}$ In the area of arms exports, as noted above, commercial and strategic interests have swept aside all ethical and ideological considerations. Nonetheless, South Africa's stance on Darfur and controversial human rights decisions in $\mathrm{UN}$ forums cannot be explained satisfactorily on the strength of interests alone. They can be explained adequately by the anti-imperialist ideology. Through this lens, the human rights violations in Darfur, Zimbabwe and Burma were viewed not on their own terms but in terms of the broader power dynamics between the North and the South, leading Pretoria to feel compelled to defend dictatorial regimes against Western criticism.

\section{The foreign policy perspective of the ANC}

What accounts for the primacy of the anti-imperialist and Africanist paradigms in South African foreign policy? The figure of Thabo Mbeki looms large in this story by virtue of his being a 'foreign policy president' but he did not write the script on his own or on a blank slate. The institutional context was provided by the ruling party and its history as a liberation movement. The Department of Foreign Affairs, which for several years after the advent of democracy in 1994 struggled to achieve cohesion, was a less significant actor.

Most reviews of Pretoria's foreign policy gloss over the perspective of the ANC, focusing instead on the country's transition to democracy as the main source of the policy. ${ }^{69}$ Yet while the transition explains the policy emphasis on democracy, human rights and resolving conflict through negotiations and power-sharing, it does not explain the Africanist and anti-imperialist world views and their dominance when in conflict with the human rights framework. These phenomena are explicable only in terms of the foreign policy's roots in the experience and Marxist-Leninist orientation of the ANC as a liberation movement. For over three decades prior to becoming the

\footnotetext{
${ }^{67}$ Laurie Nathan, 'Consistencies and inconsistencies in South Africa's foreign policy in Africa', International Affairs, 8, 2 (2005), pp. 361-372.

${ }^{68}$ Patrick Bond, Talk Left, Walk Right: South Africa's Frustrated Global Reforms (University of KwaZulu-Natal Press, Scottsville, 2004).

${ }^{69}$ For example, Alden and Le Pere, 'South Africa's post-apartheid foreign policy', p. 283.
} 
government, the ANC was supported and armed by the Soviet Union, given sanctuary by African states and vilified by Western powers. Most at home politically in the Non-Aligned Movement, it was part of the global struggle against colonialism. This history shaped profoundly the international thinking of the ruling party and its leaders and cadres who later came to serve in the post-apartheid presidency and foreign ministry.

ANC policy statements, generally ignored in studies of South African foreign policy, have considerable explanatory power, expressing in stark terms the ideas that lay at the heart of the government's approach. ${ }^{70}$ Five themes are relevant to the present discussion:

First, the fundamental principles of foreign policy - which include the promotion of human rights and democracy, the promotion of world peace and the development of the African continent - are underpinned by "our anti-imperialist, anti-colonial and anti-neocolonial commitments in international relations". ${ }^{71}$

Second, an activist international agenda is closely linked to domestic priorities. The foreign policy principles referred to above "should be seen as an essential part of defining the national interest" since global reforms will contribute to deepening and consolidating "the National Democratic Revolution" in South Africa. ${ }^{72}$

Third, the anti-imperialist struggle is not a relic of history but rather a matter of great contemporary relevance. There are several reasons for this: the primary features of the international order include the "ever-growing conflict between a highly industrialised and affluent North and an impoverished, under-developed, highly populated South"; ${ }^{73}$ Africa remains an arena in which powerful Western countries seek to advance their geo-political interests and economic objective of capital accumulation; and the

\footnotetext{
${ }^{70}$ See ANC, 'Foreign policy perspective in a democratic South Africa', 1994; ANC, 'Developing a strategic perspective on South African foreign policy', 1997; ANC, 'Resolutions adopted by the $51^{\text {st }}$ national conference of the African National Congress, Stellenbosch, 2002', 2002; ANC, 'Strategy and tactics: building a national democratic society. As adopted by the $52^{\text {nd }}$ national conference, $16-20$ December 2007', 2007; and ANC, 'ANC 52 ${ }^{\text {nd }}$ national conference 2007 resolutions', 2007. All documents available on the ANC website < $\quad$ www.anc.org.za/ancdocs $>$ (14 February 2010).

${ }^{71}$ ANC, 'Developing a strategic perspective', pg. 2.

72 Ibid, pp. 1-2.

${ }^{73}$ ANC, 'Foreign policy perspective', pg. 1.
} 
content and process of globalisation are dominated by alliances around the US, the "hyper-power" bent on regime change, whose conduct is "reminiscent of empires of a bygone era". 74

Fourth, the African Renaissance is the main pillar of foreign policy not only in relation to the continent but in all the country's international relations. This is because Africa's economic development will be a significant step in overcoming the NorthSouth divide. The key elements of the Renaissance include development, the establishment of democracy and the need to break neo-colonial relations between Africa and the world's economic powers. ${ }^{75}$

Fifth, unless developing countries in the South act in a unified manner in multilateral forums and on economic matters, "there is little chance for properly challenging the unjust world order". ${ }^{76}$ There is a need to forge alliances, develop strategies and campaign tirelessly to place the concerns of Africa and the whole of the developing world more centrally on the international agenda and to contest power relations in a range of international forums. ${ }^{77}$

In the ANC texts cited above, the anti-imperialist message does not diminish as the liberation struggle recedes into the past. On the contrary, it becomes increasingly prominent and strident over time, partly because of the unilateralist and aggressive posture of the administration of George W. Bush and partly because of Pretoria's frustration that its global reform agenda was constantly thwarted by Western states. In 2007 the ANC declared that the unilateralism and militarism of the "dominant imperialist powers" had "reared their ugly head on a scale hardly witnessed [previously] in recent history", adding that "the current global balance is evocative of the situation in previous eras of dominant empires and colonialism when brute force was the currency of geo-political intercourse". ${ }^{78}$

\footnotetext{
${ }^{74}$ ANC, 'Strategy and tactics', pg. 14.

${ }^{75}$ ANC, 'Developing a strategic perspective, pp. 6-7.

${ }^{76}$ ANC, 'Developing a strategic perspective', pg. 2.

${ }^{77}$ ANC, 'Developing a strategic perspective', pg. 8.

${ }^{78}$ ANC, 'Strategy and tactics', pg. 14.
} 
Conversely, the ANC's early foreign policy emphasis on championing human rights becomes diluted over time. In 1994 the party proclaimed that human rights would be canonised in the country's international relations and that issues of principle regarding human rights would not be sacrificed to economic and political expediency. ${ }^{79}$ Three years later the approach was much more cautious, arguing that South Africa's external influence on human rights was limited unless it acted in concert with other states and observing that the relevance and interpretation of human rights were disputed among different cultures and among countries at different levels of development. ${ }^{80}$ In the documents emanating from the ANC's national conference in 2007, there were only passing references to the international promotion of human rights. ${ }^{81}$

Because the anti-imperialist core of South Africa's foreign policy is embedded in the experience and ideology of the ruling party, it has survived Mbeki's replacement by Zuma as the country's president. Yet Zuma, unlike Mbeki, is not an ideologue, a 'foreign policy president' or an articulate champion of the cause of Africa and the South. Consequently, foreign policy under Zuma has been markedly less ambitious and assertive than under his predecessor. In light of the damage done to South Africa's reputation by Mbeki's hard-line approach, the Zuma government also appears to have recalibrated its foreign policy in favour of respect for human rights.

By way of example, in 2009 Pretoria announced that it would not abide by an AU resolution calling on member states to refuse to co-operate with the ICC's warrant of arrest against President Bashir. In a lengthy statement the foreign ministry pointed out that the resolution was a result of the UN Security Council's failure to acknowledge the AU's earlier plea that the indictment against Bashir be deferred for at least a year, "deepening the perception that Western powers treated African leaders with contempt". ${ }^{82}$ Nevertheless, South Africa was a signatory to the Rome Statute establishing the ICC, it had passed domestic legislation endorsing the Statute and it was therefore legally obliged to co-operate with the ICC. Acceptance of the AU resolution would violate the Constitution, the rule of law and "the struggle for a rules

\footnotetext{
${ }^{79}$ ANC, 'Foreign policy perspective', pg. 1.

${ }^{80}$ ANC, 'Developing a strategic perspective', pg. 2.

${ }^{81}$ ANC, 'Strategy and tactics', pg. 16; and ANC, 'ANC 52 $2^{\text {nd }}$ national conference', pg. 37.

82 'Text: South Africa legally rebuts AU resolution on arresting Bashir', Sudan Tribune, 3 August 2009, <www.sudantribune.com/spip.php?article31996> (30 June 2010), pg. 3.
} 
based international system" ${ }^{83}$ It would signal non-adherence to the constitutional values of "human dignity, the achievement of equality and the advancement of human rights and freedoms" and this would "negatively impact on our international reputation and stature as observed during South Africa's non-permanent membership of the [UN Security Council]". ${ }^{84}$

\section{Conclusion}

Pretoria's protective attitude towards Sudan in the face of the Darfur catastrophe was inconsistent with its commitment to human rights and democracy but the position was not surprising or anomalous. It reflected the central political, strategic and ideological elements of South Africa's foreign policy: a priority placed on peacemaking in Africa, in this case by promoting the implementation of the CPA and the deployment of UNAMID in Darfur; a preference for using quiet diplomacy to address conflicts and crises; and an anti-imperialist paradigm, which led to solidarity with states that were under Western pressure, regardless of their human rights performance.

It is hard to fault the analysis of inequitable global relations that underpinned the antiimperialist world view but it is equally hard to see any productive results emanating from the strategy of blocking international action against dictatorial regimes. This strategy did nothing to alter the inequities of the international system and yielded no benefits to South Africa or the South. The only winners were the dictators and the clear losers were their victims. The poor, who were the intended beneficiaries of the anti-imperialist project, ended up sacrificed on its altar. This outcome was not emancipatory or in any way transformative. In so far as it helped to retain repressive governments in power, the strategy was reactionary.

Pretoria's claim that international pressure on problematic regimes merely heightens their intransigence, and that soft diplomacy is therefore the only viable option, is plainly ahistorical. When Foreign Minister Dlamini-Zuma defended South Africa's voting record on the UN Security Council by stating that the country's experience had taught it the value of seeking negotiated solutions, she ignored the fact that South

\footnotetext{
${ }^{83}$ Ibid, pg. 5.

${ }^{84}$ Ibid, pp. 5-6.
} 
Africa's negotiations were the product of a liberation struggle reinforced by sustained international campaigns against the apartheid regime. As the ANC argued at the time, the Western powers that pursued 'constructive diplomacy' with the regime retarded the struggle. In the absence of sustained pressure on Sudan, Khartoum has not been constrained in Darfur and has had no incentive to adopt a more accommodating attitude towards the rebel movements. 